ACTA THERIOLOGICA

Vol. 33, 7: 79-85, 1988

\title{
Seasonal Patterns in the Wood Mouse Population in Mediterranean Scrubland
}

\author{
Sacramento MORENO \& M. Beatriz KUFNER
}

\begin{abstract}
Moreno S. \& Kufner M. B., 1988: Seasonal patterns in the wood mouse populations in Mediterranean scrubland. Acta theriol., 33, 7: 79-85. [With 2 Figs.]

Annual breeding and density variation patterns were studied for the wood mice in a Meditterranean scrubland of southwest Spain. Snap and live trapping methods were utilized. Variation in testicle and seminal vesicle sizes and pregnancy showed that reproductive activity extended from August to April which does not agree with other areas of Central and North Europe. However, the density variation, the seasonal disappearance rate and residency time in our area had a population cycle similar to Central and North Europe. The causes of this disagreement are discussed. España]

[Estación Biológica de Doñana, CSIC, Apdo. 1056, 41080 Sevilla,
\end{abstract}

\section{INTRODUCTION}

The reproductive cycle of the wood mouse, Apodemus sylvaticus (Linnaeus, 1758), in Europe shows its maximum in summer and its minimum in winter, producing the highest peaks in population density in autumn and winter, and the lowest, in spring and summer (e.g. Saint Girons, 1967; Montgomery, 1980; Smal \& Fairley, 1982; and others). Soriguer and Amat (1979) found a similar seasonal pattern of abundance in the wood mice in a mountainous area of southern Spain, and also Jamon (1986) in the Camargue, a flat area in southern France. However, preliminary work in the Doñana area, a plain by the sea in southwestern Spain, suggests a yearly breeding cycle different from those found in most of Europe (Moreno, 1984a), which could affect seasonal patterns of abundance. The purpose of this paper is to analyze (on a monthly basis) the breeding conditions, density, disappearance rate and residency time of the wood mouse population inhabiting the Mediterranean scrubland of the Doñana National Park.

\section{STUDY AREA AND METHODS}

Donana National Park is located in the southwest of the Iberian Peninsula $\left(37^{\circ} \mathrm{N}, 6^{\circ} 2^{\prime} \mathrm{W}\right)$. It includes three main biotopes: the marsh which is flooded in autumn-winter and dry in spring-summer; the dunes, lying by the edge of the 
sea; and the scrubland. There are two types of scrubland: a hygrophytic scrubland made up mainly of Ericaceae, and a dry, xerophytic scrubland made up mainly of Cistaceae. Climate is Mediterranean with Atlantic influence. Winters are mild and rainy and summers hot and dry. Most of the rainfall (average $524 \mathrm{~mm}$ ) occurs from October to February. Average temperature in January is $11^{\circ} \mathrm{C}$ and in August $25^{\circ} \mathrm{C}$.

Wood mice were captured with snap-traps (from March 1978 to February 1980) and live-traps (from October 1978 to December 1979 and from May 1984 to May 1985), in the dry, more Meditterranean scrubland. In order of importance, other species of small mammals captured in the area were Eliomys quercinus (Linnaeus, 1766), Mus spretus (Lataste, 1883), Rattus rattus (Linnaeus, 1758) and Crocidura russula (Hermann, 1780).

To study the breeding patterns, 4500 snap trap-nights were set '(an average of 300 traps a month) and 262 wood mice were captured. Large testicles and full seminal vesicle in males, and lactation and pregnancy in females indicated breeding condition. Litter size was estimated by counting the number of embryos.

To study the population density, 5632 trap-nights distributed in 22 sessions were used during the first period and 5436 trap-nights in 7 sessions during the second period. A total of 113 wood mice were captured at 192 times. Live trapped animals were weighed, identified by toe clipping, examined for breeding condition and parasites, and released in the same place. Population size was estimated according to the Calendar of Catches (CC) (Petrusewicz \& Andrzejewski, 1962).

Density was calculated by relating the population size to the surface area of the study area $\left(11025 \mathrm{~m}^{2}\right.$ and $\left.6400 \mathrm{~m}^{2}\right)$ plus the average distance between successive recaptures ( 43.3 and $28.5 \mathrm{~m}$, respectively) in each period of sampling. Seasonal rate of disappearance $\left(P_{\mathrm{o}}\right)$, was calculated by using the coefficient of Andrzejewski \& Wierzbowska (1961):

$$
P_{\mathrm{o}}=N / N_{\mathrm{m}}(t+0.5)
$$

where $N_{\mathrm{m}}$ is the number of animals which survive $0,1,2, \ldots m$ sampling periods, $t$ is the number of sampling sessions each mouse survives, and $N$ is the total number of trapped animals. Therefore the residence time will be $1 / P_{0}$.

\section{RESULTS}

\subsection{Breeding Patterns}

Reproductive activity showed the same annual pattern for both years of study. Variation in testicle and seminal vesicle size (Fig. 1) indicated that sexual activity extended from August to April, with a slight drop in the winter months. The highest percentage of active males was observed in October-November. Although scarce, data for the summer months showed the absence of sexual activity.

Reproductive activity in females followed a similar pattern. Pregnant females were found from October to April and only one in August. No pregnant females were captured from May to July. We have no data for September.

Average litter size was $4.53(n=59)$ and ranged from 3 to 6 . Although 
there is no numerical data on testicular size or pregnancy, similar results on the annual breeding variation (relative testicle size or palpation of pregnancy) during 1984-1985 were obtained.

\subsection{Population Density}

Yearly variations in population density are shown in Figure 2. Numbers began to increase in September, reaching the highest value in December-Janury and decreasing in March to the lowest density between May and July.

$\mathrm{CC}$ indicates that the population increase in the first autumn (September-October) was mainly due to adult specimens. Most of the first

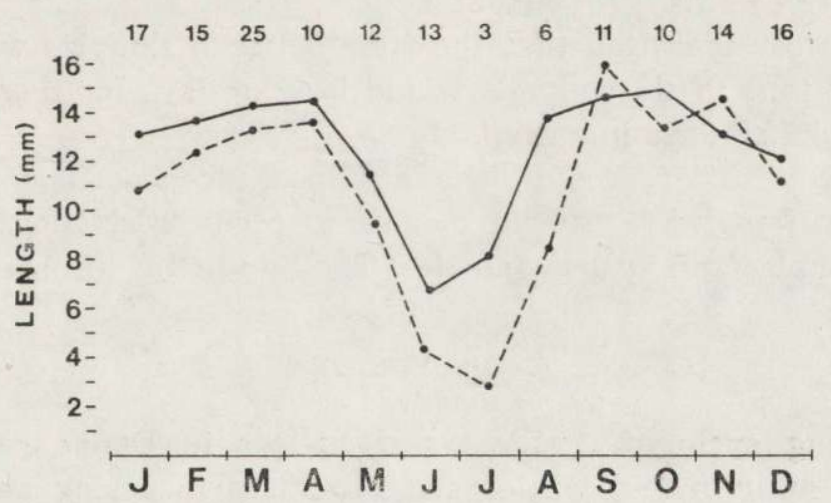

Fig. 1. Annual variation in average size of testicle (continuous line) and seminal vesicle (broken line) of Wood Mice in scrubland of Doñana National Park. In top: sample sizes.

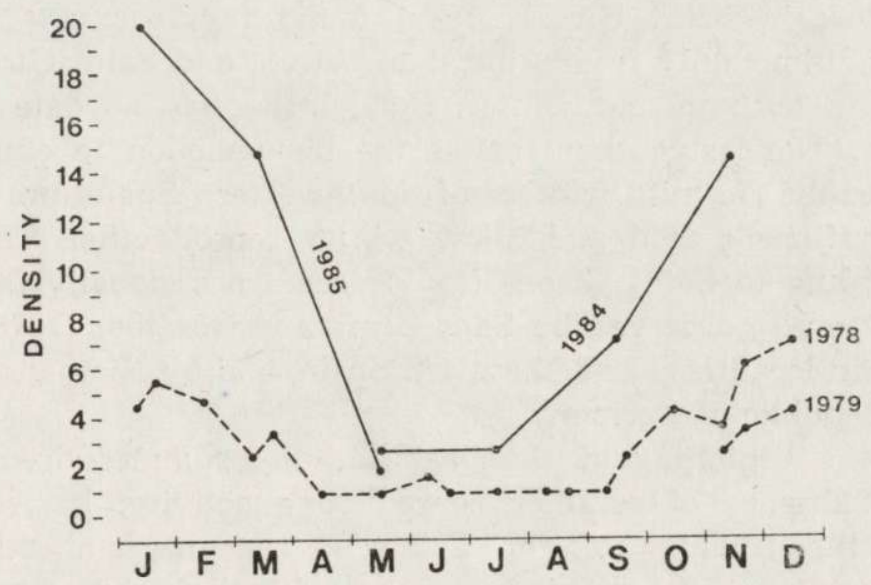

Fig. 2. Annual variation in population density (individuals/ha) of Apodemus sylvaticus. 
captures of young animals (weighing less than $20 \mathrm{~g} ; \mathrm{n}=21$ ) occurred between November and Janury. The small number of juveniles captured in spring (from March to May) $(n=4)$ suggests that the post-winter reproductive peak has a slight influence on the recruitment rate.

Population density ranged from 6.8 indiv./ha in December to 0.9 indiv./ ha from April to September during 1978-1979 and from 20.0 indiv./ha in January to 2.5 indiv./ha from May to July during $1984-85$.

\subsection{Seasonal Residency Time and Disappearance Rate}

Disappearance coefficient $\left(\mathrm{P}_{\mathrm{o}}\right)$ for the animals recruited in autumn (September to December) $\left(\mathrm{P}_{\mathrm{o}}=0.35\right)$ was lower than for those recruited in spring (March to May) $\left(P_{\mathrm{o}}=0.62\right)$.

Taking into consideration that the time between samples was 20 days, the residency time of the animals would be 54.6 days for those recruited in autumn and 32.2 days in spring.

No significant differences in the disappearance coefficient of males $\left(P_{\mathrm{o}}=0.46\right)$ and females $\left(P_{\mathrm{o}}=0.50\right)$ seemed to occur, residency time being 43.1 days in males and 40.0 in females. The maximum life span observed was 346 days.

\section{DISCUSSION}

The breeding cycle of Apodemus sylvaticus in Donana, which was maximum in autumn and winter and minimum in spring and summer, differs from that of other areas in Europe (Saint Girons, 1967; Jüdes, 1979; Smal \& Fairley, 1982; Jamon, 1986). However, it shows a great similarity to the breeding cycle of North African wood mice. In Tunisia, Bernard (1969; in Saint Girons, 1972) found in Apodemus sylvaticus breeding conditions only from August to March, and Saint Girons (1972) in Morocco in autumn and winter, though she has no data in spring and summer. The last author relates the phenomenon to climatic conditions. Probably the mild winters of Southwestern Spain, provide wood mice with sufficient food and allow winter reproduction. This phenomenon according to Saint Girons (1967) occurs occasionally in southern France. It was also observed by Sans Coma and Gosálbez (1976) in some Mediterranean localities of northeastern Spain, and by Niethammer (1978) in Federal Republic of Germany.

In May, the beginning of the heat and the summer drought could explain the absence of summer reproductive activity. In August and September, the ripening of the Cistaceae capsules and other fruits (Rubus, Corema), which are likely sources of food for wood mice, could allow reproduction again.

Further research is needed to confirm if this breeding pattern is more 
or less invariable interannually or if it changes according to environmental conditions. In any case we have found a similar cycle during the two years of study.

Population density showed a great interannual variability, being in 1984 three fold greater than in 1978. Possibly the density of wood mice increased due to the scrub protection in Donana National Park (Kufner, 1986). However the numbers of Apodemus sylvaticus in Donana appeared between the limits usually reported for this species (Hansson, 1968; Green, 1979). The pattern of seasonal variation in population density stays and it is the same as usually found in other European populations (Wats, 1969; Southern, 1979; Gurnell, 1978 and Montgomery, 1980, in England; Smal \& Fairley, 1982, in Ireland; Jamon, 1986, in the French Camargue; Vericad, 1977, in the north of Spain; Saint Girons, 1967, in France).

The best explanation as to why different seasonal breeding in Doñana and the rest of Europe yield the same variation in density pattern is the differential spring and autumn disappearance rates and residency times. The individuals caught in spring disappeared quickly and many of the young born in this season were not recruited. Kufner (1986) found an increase in the number of wood mice in summer in the hygrophytic scrubland, which suggests a possible migration from the xerophytic scrubland. However, the summer drought, the increase of parasitism (Moreno, in prep.) and probably some competition with Eliomys (Moreno, $1984 \mathrm{~b})$ could be sufficient reasons to account for a high summer mortality.

More studies are necessary to understand how the wood mice and other European small mammals populations adapt their life history pattern to Mediterranean conditions.

Acknowledgement: We acknowledge the help from Dr. Miguel Delibes of the Estación Biológica de Doñana, CSIC, (Sevilla, España) and from Dr. Oliver Pearson of University of California (Berkeley, California). This work was partly financed by CSIC-CAICYT (projet 944).

\section{REFERENCES}

1. Andrzejewski R. \& Wierzbowska T., 1961: An attempt at assessing the duration of residence of small rodents in a defined forest area and the rate of interchange between individuals. Acta theriol., 5: 153-172.

2. Green R., 1979: The ecology of wood mice (Apodemus sylvaticus) on arable farmland. J. Zool., Lond., 188: 357-377.

3. Gurnell J., 1978: Seasonal changes in numbers and male behavioural interaction in a population of wood mice Apodemus sylvaticus. J. Anim. Ecol., 47: 741-755.

4. Hansson L., 1968: Population densities of small mammals in open field habitats in south Sweden in 1964-67. Oikos, 19: 53-60. 
5. Jamon M., 1986: The dynamics of wood mouse (Apodemus sylvaticus) populations in the Camargue. J. Zool., Lond. (A), 208: 569-582.

6. Jüdes U., 1979: Untersuchungen zur OKologie der Waldmaus (Apodemus sylvaticus Linné, 1758) und der Gelbhalsmaus (Apodemus flavicollis Melchior, 1834) im Raum Kiel (Schleswig-Holstein). Z. Säugetierk., 44: 81-95

7. Kufner M. B., 1986: Tamaño, actividad, densidad relativa y preferencias de hábitat de los pequeños y medianos mamíferos de Doñana como factores condicionantes de su tasa de predación. Tesis Doct. Univ. Autónom. de Madrid, España.

8. Montgomery M., 1980: Population structure and dynamic of sympatric Apodemus species (Rodentia: Muridae). J. Zool., Lond., 192: 351-377.

9. Moreno S., 1984a: Datos sobre la reproducción del ratón de campo (Apodemus sylvaticus) en la Reserva Biológica de Doñana. [In: "Actas II Reunión Iberoam. Cons. Zool, Vert.” J. Castroviejo, ed.]: 329-338. Cáceres, 1980.

10. Moreno S., 1984b: Biometría, biología y dinámica poblacional del lirón careto, Eliomys quercinus (L.), en Doñana. Tesis Doctoral. Univ. de Granda, España.

11. Niethammer J., 1978: Apodemus sylvaticus (Linnaeus, 1758). Waldmaus. [In: "Handbuch der Säugetiere Europas. Band I Negetiere I" J. Niethammer und F. Krapp, Eds.]. Akademische Verlagsgesellschaft: 337-358. Wiesbaden.

12. Petrusewicz K. \& Andrzejewski R., 1962: Natural history of a free-living population of house mice (Mus musculus Linnaeus) with particular reference to grouping within the population. Ekol. Polska, Ser. A, 10: 85-122.

13. Saint Girons M.-C., 1967: Etude du genere Apodemus Kaup, 1829 in France. Mammalia, 31: 55-100.

14. Saint Girons M.-C., 1972: Le genre Apodemus Kaup, 1829, au Maroc. Z. Säugetierk., 37: $362-371$.

15. Sans Coma V. \& Gosálbez J., 1976: Sobre la reproducción de Apodemus sylvaticus L., 1758 en el nordeste Iberico. Miscelánea Zoológica, III: 227-233.

16. Smal C. M. \& Fairley J. S., 1982: The dynamics and regulation of small rodent populations in the woodland ecosystems of Killarney, Ireland. J. Zool., Lond., 196: $1-30$.

17. Soriguer R. C. \& Amat J. A., 1979: Datos sobre la biolgía y dinámica numérica de una población de ratones de campo (Apodemus sylvaticus) en Andalucia occidental. Bol. Est. Cent. Ecol., 8: 79-83.

18. Southern H. N., 1979: The stability and instability of small mammal populations. [In: "Ecology of small mammals" D. M. Stodart Ed.]. Chapman and Hall: 103-312, London.

19. Vericad J. R., 1977: Experiencia de marcado-recaptura con tres species de micromamíferos forestales en San Juan de la Peña (Huesca). Cent. Pir. Biol. Exp., 8: 123-142.

20. Wats C. H. S., 1969: The regulation of wood mouse (Apodemus sylvaticus) numbers in Wytham Woods, Berkshire. J. Anim. Ecol., 38: 285-304.

Received 24 March 1987, Accepted 4 September 1987. 
Sacramento MORENO i M. Beatriz KUFNER

\section{SEZONOWA DYNAMIKA LICZEBNOSCI I ROZRODU MYSZY ZAROSLOWEJ W WARUNKACH SRODZIEMNOMORSKICH}

\section{Streszczenie}

Badano sezonowość rozrodu i zmian zagęszczenia myszy zaroślowej żyjącej w trawiasto-krzaczastych ekosystemach południowo-zachodniej Hiszpanii. Stosowano pułapki zabijające i żywołowne. Na podstawie zmian w wielkości jąder i kanalików nasiennych u samców oraz ciąży u samic stwierdzono, że okres rozrodu trwal od sierpnia do kwietnia, tj. inaczej niż w Europie Srodkowej i Północnej (Ryc. 1). Natomiast sezonowa dynamika zagęszczenia i tempa ubywania osobników $\mathrm{z}$ populacji oraz czas osiadłości były na badanym terenie podobne jak w Europie Srodkowej i Pólnocnej (Ryc. 2). W pracy dyskutowane są przyczyny stwierdzonych różnic. 